\title{
Jeg sa unnskyld!
}

\section{Om tilgivelsens innhold og relevans $i$ mote med barn og unge}

\section{Av Tormod Kleiven}

Artikkelen behandler spørsmålet om hvilket innhold og relevans tilgivelse har $i$ mote med barn og unge i familie, barnehage, skole og innen trosopplaringssammenheng. Tilgivelse som begrep og fenomen diskuteres ut fra en analyse av faglitteratur innen filosofi, psykologi og teologi, og $i$ lys av teori om minneforståelse og relatert til målgruppa. Artikkelens andre del omhandler temaer som analysen har aktualisert med tanke på hvordan tilgivelse og forsoning kan formidles og praktiseres $i$ mote med barn og unge. Diskusjonen legger til grunn at tilgivelse er et resultat av et oppgjør hvor den som er såret, oppdager at hun eller han har en endret og frigjørende posisjon til den som har såret. Dette innebarer også at tilgivelse først og fremst formidles og modelleres som en livsforståelse og holdning, mer enn som et oyeblikks handling.

Nøkkelord: Tilgivelse, forsoning, oppgjør, minner

TORMOD KLEIVEN (f. 1955), professor og senterleder ved VID vitenskapelige høgskole. Adresse: postboks 184 Vinderen, 0319 Oslo.E-post: tormod.kleiven@vid.no

\section{INNLEDNING}

En god venn av meg fortalte følgende historie:

Han hadde sett sønnen på 6 år stå og kaste stein $i$ dammen hvor det svømte gjess, og sa at det måtte han holde opp med. Han kunne treffe en av gjessene. Etter en stund kom sønnen inn og sa: «Jeg sa unnskyld». Farens mistanke ble bekreftet. En gås lå livløs på bunnen av dammen.

Historien forteller at gutten hadde lært å si «unnskyld» når han hadde gjort noe galt. Det er likevel ikke alltid det hjelper å beklage det som har skjedd. Gåsa var uansett like død. Samtidig kan det å si unnskyld være en måte å erkjenne at en gjorde feil. Det åpner opp for å plassere ansvar. Oppgjør og mulighet for tilgivelse er et tema som har relevans for mennesker i alle aldre, også for barn og unge. Tilgivelse som tema og fenomen er et sentralt anliggende både i trosopplæring, barnehage, skole og i mange hjem. Det er nevnt i formålsparagrafen både for barnehage ${ }^{1}$ og skole ${ }^{2}$.

1 https://lovdata.no/dokument/NL/lov/2005-06-17-64/KAPITTEL_1\#KAPITTEL_1

2 https://lovdata.no/dokument/NL/lov/1998-07-17-61

Prismet - IKO-Forlaget 2021

Tilgjengelig på https://journals.uio.no//prismet. Publisert under CC BY-NC 4.0. Fagfellevurdert

Årgang 72, hefte 3, s. 215-232 
Tilgivelse uttrykker, sammen med forsoning, omsorg og kjærlighet, viktige byggesteiner i det å leve godt og rett med hverandre. Paul-Leer Salvesen hevder at det ikke er mulig å gi en uttømmende definisjon av tilgivelse (Hammerlin \& Leer-Salvesen 2014, 159). Jeg tror begrunnelsen hans er at tilgivelse (i likhet med kjærlighet) kan beskrives, men først og fremst gir mening i en konkret sammenheng og gjennom livsfortellinger. Et universelt kjennetegn ved tilgivelse og forsoning er imidlertid at den endrer posisjoner hos en eller flere av de som er involvert. ${ }^{3}$

Denne artikkelen ønsker å besvare hvordan begrepet og fenomenet «tilgivelse» beskrives innen faglitteratur, og hvordan tilgivelse kan formidles og praktiseres $i$ mote med barn og unge sett $i$ lys av dette. Vi er avhengig av en forståelse av hva som er tilgivelsens innhold, som grunnlag for å drøfte hvordan den kan formidles og praktiseres med fokus på barn og ungdom. Målet med artikkelen er ikke å formidle en undervisningsmetodikk eller pedagogisk tilnærming, men å bidra med kompetanse til å møte barn og unge på en adekvat måte når tilgivelse blir aktualisert $\mathrm{i}$ hverdagen.

Artikkelen analyserer hvordan faglitteratur innenfor filosofi, psykologi og teologi beskriver innholdet $\mathrm{i}$ tilgivelse. Materialet er basert på et systematisk litteratursøk, ${ }^{4}$ og består av cirka 50 faglige artikler og bøker som er utgitt i nordisk eller engelsk språkdrakt. Analysen identifiserer beskrivelser og definisjoner av tilgivelse i litteraturen. Dette er grunnlaget for å systematisere materialet innenfor tre overordnede kategorier. I materialet er forsoningsbegrepet til dels sammenvevd med forståelse av tilgivelse. Derfor er dette begrepet tatt med i analyse og drøfting. I tillegg til teoritilfanget som analysen av begrepene tilgivelse og forsoning gir, er forståelse av minner et supplerende teoretisk perspektiv som grunnlag for analyse og drøfting.

Etter å ha presentert teori knyttet til minneforståelse vil anvendt faglitteratur beskrives, analyseres og reflekteres over med fokus på barn og unge. Andre del av artikkelen drøfter temaer som har relevans når barn og unge blir krenket og krenker, og som analysen aktualiserer.

\section{Minneforståelse}

Spørsmål om tilgivelse og forsoning er knyttet til faktiske hendelser. Hvordan en husker det som har skjedd, er basert på faktakunnskap om tid, sted og hvem som var til stede. Samtidig fortelles historien ut fra det perspektivet og den posisjonen den enkelte hadde $i$ hendelsen. Innenfor denne referanserammen formes minner. Dennis Rothermel $(2011$, s. 5) hevder at arbeid med minner er et helt nødvendig redskap for den som i en konflikt har blitt utsatt for ødeleggende uforsonlighet.

3 Forståelse og betydningen av tilgivelse i historisk lys (bl.a. i gresk, hebraisk og tidligere kristen tradisjon) er beskrevet av David Konstan (2010).

4 Litteratursøket er gjort i flere omganger. Følgende søkemotorer er anvendt: EBSCO, Atlas, Idunn, Oria 
Han understreker nødvendigheten av at den utsatte husker hva som skjedde, for å fastholde behovet for et oppgjør med det vonde. Det er alltid en fare for at ansvarlige kan formidle hva som skjedde slik at de avviser eller overser det vonde. Voksne kan bruke sin autoritet til å bagatellisere den dypt sårende opplevelsen hos barnet slik at det velger å tie. Minnet kan da endre karakter til å prege barnets selvforståelse framfor å be om hjelp til å stå opp mot urett.

Minner er ikke primært faktakunnskap, men snarere perspektivistisk viten om noe som har skjedd. Primo Levi $(1989$, s. 23) skriver at minnet er fantastisk, men like fullt et uholdbart redskap 5 , og Miroslav Volf (2006, s. 30) hevder at minner er «notoriously unreliable». Det er fullt mulig å ha tillit til faktabaserte opplysninger som eksempelvis sted og tidspunkt hendelsene skjedde og å ha omforente minner om i hvert fall deler av de faktiske hendelsene i situasjonen. Påstandene til Levi og Volf oppfatter jeg er knyttet til hvordan hendelsene oppfattes. Det har sammenheng med at enhver er begrenset $i$ tid og rom når en husker og forteller sine historier (Volf, 2006, s. 50). Hva hendelsene betyr, forankres med andre ord i hvordan virkeligheten ser ut sett fra partenes ståsted og posisjon. I møte med barn som forteller om hvorfor de er blitt lei seg, er dette åpenbart. De har begrenset evne til å se det som skjedde fra den andres posisjon uten at de får hjelp til dette. Det samme gjelder også i stor grad voksne. Dersom ens eget perspektiv anses som det eneste som er sant, begrenser det muligheten til å skape et klima for oppgjør hvor begge parter kan se hendelsen fra flere posisjoner.

Paul Ricoeur peker på tvetydigheten ved minner og beskriver dem som «the presence of the absent» (2004, s 19). Minnene er nåtidsbilder av det vi husker har skjedd i nær eller fjern fortid. Samtidig hevder han at mennesket har mulighet til å arbeide med minnene slik at de kan huskes og omsettes i nye handlingsvalg (Ricoeur, 2004, s. 4). Volf (2006, s. 67) legger Ricoeur til grunn når han hevder at minner er også en form for handling, og ikke bare noe vi vet. Dette understreker både utfordringer og muligheter som er til stede i et hvert samspill, og ikke minst når begge parter er avhengige av at relasjonen varer over tid. Mulighet for ny atferd i møte med hverandre forutsetter at vi får tilgang til perspektiver som utdyper og omformer minnene og dermed selvforståelse og virkelighetsbilde.

Gordon Mordechai (2015, s. 502) hevder at bare den som forholder seg til fortiden, kan gå inn i en prosess hvor en kan gi slipp på det kravet fortiden har på ens identitet og forpliktelser. En forsoningsprosess hvor oppgjør og tilgivelse blir aktualisert, åpner opp for muligheter til nyskapende virkelighetsforståelse. Forsoning innebærer at den som blir såret og den som har såret ikke lenger lar fortiden definere framtiden (Staub 2005, s. 444). Det forutsetter at begge parter erfarer en frigjørende oppreisning både ved å bære eget ansvar og ved å godkjenne andres erkjennelse av sin ansvarlighet.

5 Primo Levi skriver dette i sin bok med bakgrunn og referanseramme fra å være fange i konsentrasjonsleiren Auschwitz under siste verdenskrig, 


\section{HVA ER TILGIVELSE? \\ Hvordan forstå tilgivelse og forsoning?}

Forståelse av tilgivelse i norsk sammenheng er preget av den kristne kulturarven i landet vårt. Bibelens nye testamente anvender to greske begrep som er oversatt med «tilgivelse». I evangeliene brukes ordet afiêmi, og som betyr «å la noe fare». Det er mulig å legge det vonde bak seg slik at det ikke lenger er styrende for livet i nåtid. Afiêmi brukes blant annet i bønnen «tilgi oss vår skyld, slik også vi tilgir hverandre» (Matt 6,12). Den paulinske brevlitteraturen anvender verbet charizomai, som betyr «å være sjenerøs». Søren Kierkegaard forankrer tilgivelsen i kjærlighetens vesen. Han skriver at «saaledes troer den Kjerlige ved Tilgivelsen det Synlige bort» (2011, s 102). Sitatet beskriver sjenerøsitetens vesen. Begge disse greske begrepene sier noe om hva som tilgivelse resulterer i, men i liten grad hva som er veien fram til dette resultatet.

Forsoning og tilgivelse blir ofte knyttet sammen uten at det nødvendigvis er en direkte sammenheng mellom disse (Dwyer 2003, s. 106). Det latinske ordet for forsoning, «reconciliare», betyr å «øre sammen igjen» (Leer-Salvesen, 2009, s. 12). Det som var splittet både i et menneske og mellom mennesker, blir helet eller ført sammen. Det språklige innholdet i forsoningsbegrepet kan også tydeliggjøre den prosessuelle siden av forsoning. Forsoningsarbeid er å avklare premissene for å kunne «føre sammen» partene til en dialog om det som skiller dem. Dette kan igjen innebære et oppgjør som aktualiserer tilgivelsens mulighet (Augsburger 1996, s. 125; de Gruchy 2002, s. 177).

Livsforsoning er et begrep som er anvendt om det helingsarbeidet som skjer i et menneske (Leenderts 2018, s. 179). Det innebærer en bearbeiding hvor en kommer til rette med negativt pregende livserfaringer «slik at de får en rettmessig plass i livshistorien uten å prege og styre livsforståelsen i nåtid» (Kleiven, 2015, s. 189).

I analysen som følger, er faglitteraturen systematisert $i$ tre underoverskrifter. Systematiseringen er et resultat av analysen jeg har gjort av forskningslitteraturens forståelse av tilgivelse. Den er en sortering av ulike hovedtilnærminger til forståelse av tilgivelse. De tre overskriftene er:

1. Tilgivelse sett $i$ lys av kristen trosformidling. Tilnærmingen kan beskrives som en praktisk teologisk tilnærming.

2. Tilgivelsens plass og funksjon $i$ eget liv. Dette er faglitteratur som primært diskuterer hvordan det enkelte menneske kan forholde seg til krenkende hendelser i sitt liv slik at vedkommende kan oppnå en tilgivende holdning. Den har med andre ord et individuelt og intrapsykisk fokus.

3. Tilgivelse som et mellommenneskelig anliggende. Fokus er på hvordan

6 Ordet er anvendt om forsoning både i engelsk og andre europeiske språk. 
tilgivelse og forsoning aktualiseres $\mathrm{i}$ forholdet mellom to parter når den ene er blitt utsatt for krenkelser eller de er i konflikt med hverandre.

Det som kjennetegner punkt 1 og 2 i denne systematiseringen er et tilnærmet ensidig fokus på den som er krenket og kan gi tilgivelse. Når tilgivelse behandles som et mellommenneskelig anliggende (punkt 3), vil forholdet mellom krenker og den krenkede stå sentralt.

\section{Et praktisk teologisk fokus: \\ Tilgivelse sett i lys av kristen trosformidling}

Jeg vil peke på tre perspektiver som står sentralt $\mathrm{i}$ en teologisk tilnærming til tilgivelse.

Tilgivelse er et under, den kan oppleves som overraskende, ufortjent godhet. Filosofien karakteriserer det som «a supererogatory action» forstått som ikke nødvendig og dermed heller ikke forventet (Gamlund 2009, 11, de Lange 2004, 163). Richard Holloway $(2002,85)$ beskriver tilgivelse som ren og ufortjent omsorg som er gitt i uforbeholden kjærlighet. ${ }^{7}$ For å understreke dette låner han Jacques Derridas ord; at tilgivelse «is a madness of the impossible». Den franske filosofen Vladimir Jankélévitsch ${ }^{8}$ hevder at vi tilgir når vi ikke har noen grunn for å tilgi, og om vi har begrunnelser for å tilgi som unnskylder det som har skjedd, så er ikke det tilgivelse $(2005,107)$. Dette underbygger at tilgivelse ikke er begrunnet $i$ hva den andre gir av forklaringer eller unnskyldninger, men i det ubegrunnede og uforståelige. I møte med barn og unge kan nettopp det ubegripelige være en døråpner til å forankre tilgivelsen i oppdagelsen av en frigjørende mulighet. Denne tilnærmingen kan i så måte stå i motsetning til en regissert prosess hvor den som har gjort noe sårende, blir pålagt å be om tilgivelse.

Tilgivelse blir også beskrevet som et kjennetegn ved det kristne fellesskapet. L. Gregory Jones (1995) hevder at "forgiveness is not so much a word spoken, an action performed, or a feeling felt as it is an embodied way of life in an ever-deepening friendship with the Triune God and with others». Tilgivelsen blir det kroppsliggjorte uttrykk for menighetens indre liv, og ansett som selve Gudsriketegnet. I kristen tro er den ultimate tilgivelsen knyttet til Guds vilje og evne til å tilgi mennesket ved at han selv i Jesu skikkelse tok et oppgjør med døden som ondskapens konsekvens. Anthony Bash (2007, s. 177) peker på det guddommelige i mellommenneskelig tilgivelse og beskriver det å tilgi som «å imitere Gud». ${ }^{9}$ I et kristent fellesskap kan Guds tilgivelse formidles til barn og unge som noe Gud gir uforbeholdent til alle mennesker, men at Guds tilgivelse også kan være et forbilde for hvordan oppgiør

7 Holloway skriver at tilgivelse er «a miracle of pure unmerited care, given out of uncalculating lov»

8 Roar Iversen (2013) presenterer i sin doktoravhandling mer inngående Jankélévitch og hans forståelse av tilgivelse.

9 Bash skriver at «Human forgiveness has its prototype in divine forgiveness and is imitative of God» 
mellom mennesker kan bidra til forsoning og tilgivelse som en frigjørende mulighet. Disse to perspektivene på tilgivelsen mellom mennesker understreker tilgivelse mer som en livsforståelse og et fellesskapsbærende preg enn som punktuelle handlinger. Ethvert fellesskap har behov for å ta et oppgjør med at mennesker tråkker på hverandre, blir såret og krenket. Dersom tilgivelse skal være fellesskapets byggestein, forutsetter det at den som opplever seg krenket, blir lyttet til, og at ansvar blir avklart og plassert hos den som har et nødvendig maktpotensial til å krenke den andre. Alternativet vil være at tilgivelse blir misbrukt for å beskytte den som er i maktposisjon.

En kristen livsforståelse peker på sammenhengen mellom Guds tilgivelse og mellommenneskelig tilgivelse. Teologisk og kristen litteratur sier at det å tilgi sin neste er en forutsetning for Guds tilgivelse (Murphy, 2003, s. 92; Luther 1952, s. 158), og det beskrives som et vilkår for å tilhøre det kristne fellesskapet (Kleiven, 2011). Etter min vurdering er det en feilslutning når tilgivelse framstilles som en kristenplikt. En tro på den kristne Gud er en tro på at Gud kan skape under som gjør tilgivelse mulig hos et menneske som er blitt krenket. Men denne troen må også gi rom for at tilgivelse ikke er mulig eller rett her og nå. Hvis ikke, kan tilsagn om tilgivelse innebære en ny krenkelse som resulterer $i$ «en nedvurdering av eget verd» (Henriksen 2008, 216). Det er derfor nødvendig å argumentere for en forståelse av hva som menes med bønnen «tilgi oss vår skyld, slik vi også tilgir våre skyldnere» (Matt 6,12) som tydeliggjør at verken Guds tilgivelse eller den mellommenneskelige tilgivelse er en forutsetningsløs plikt. ${ }^{10}$

\section{Et intrapsykisk fokus:}

\section{Tilgivelsens plass og funksjon i det enkelte menneskes liv}

Mye av faglitteraturen har fokus på hvordan det sårede mennesket kan gjøres i stand til å tilgi. Dette knyttes til vilje og holdning, men også til behovet for en bearbeidelsesprosess. Everett Worthington (2006) beskriver tilgivelse både som prosess og beslutning. At tilgivelse er en beslutning, innebærer at den som er såret, tar kontroll over behovet for gjengjeldelse og hevn ut fra et mål om å gjenopprette relasjonen til den andre slik den var før hendelsen. Robert D. Enright (2001, s. 31) sier at tilgivelse er basert på en indre beslutning hos den som er såret. ${ }^{11}$ Samtidig

10 I en tidligere artikkel har jeg beskrevet to forutsetninger for Guds tilgivelse, og som også har gyldighet på det mellommenneskelige plan (Kleiven 2011, s. 47-48): Guds tilgivelse forutsetter for det første et oppgjør hvor ansvaret er plassert og synliggjort for alle dette angår. Jesus tok på seg ansvaret på vegne av menneskeheten ved å dø på korset. Tilgivelse mellom mennesker forutsetter også at ansvaret er plassert og formidlet til alle som krenkelsen angår. Den andre forutsetningen er at den som tilgir, må ha makt til å tilgi. Jesus synliggjorde på korset at han ikke kunne tilgi de som korsfestet ham, fordi han menneskelig sett var avmektig. Derfor ba han Gud om å tilgi dem (Luk 23,34; jfr. Keene, 1995). På samme måten er den som tilgir, avhengig av å være frigjort fra det maktgrepet som krenkeren har både på det ytre plan (som et barn må slippe å være utsatt for en voldelig far) og på det indre plan (ved at krenkeren ikke lenger har makt til å fastholde en løgnbasert virkelighetsforståelse i den krenkedes liv).

11 Enright skriver at tilgivelse «is the moral action of one individual that starts as a private act, an unseen decision within the human heart». 
betegner han tilgivelse som paradoksal; tilgivelse er et alternativ til å fastholde nag og sinne mot den skyldige, men hvor retten til å bære nag samtidig er en forutsetning for å gjøre et slikt valg. ${ }^{12}$ Tilgivelse forstått både som et viljesvalg og en bearbeidelsesprosess, har vært grunnlaget for å utvikle ulike fasemodeller for $i$ holdning og handling kunne etablere en vilje til å tilgi. Det er også beskrevet tilnærminger som sammenholder vilje og bearbeiding med en mer relasjonell forståelse av tilgivelse (Worthington 2006).

Tilgivelse kan forstås som holdning og dyd. Tilgivelse forstås da mer som endring av holdning enn ytre handling. Carl-Reinhold Bråkenhielm går den motsatte veien når han hevder at tilgivelse uttrykkes i handling, men at handlingen kan «sägas vara uttryck för en dygd, nämligen dygden at älska» $(1987,65)$. Denne forståelsen innebærer en relasjonell tilnærming ved at handlinger som uttrykker vilje til å tilgi, rettes mot den som et forsoningsarbeid angår.

Fokus på tilgivelsens plass og funksjon hos den som er blitt såret og krenket, understreker de muligheter et menneske har til å bearbeide sårende opplevelser. Det er et oppgiør med forestillingen om at mennesket utelukkende er et offer for omstendighetene. En bearbeidelsesprosess kan være en bemyndigende maktbevegelse som bidrar til å reise mennesker opp og sette ham eller henne bedre $\mathrm{i}$ stand til å forholde seg konstruktivt til den som krenket. En ensidig intrapsykisk tilnærming kan samtidig formidle at den krenkede må tilgi for sin egen skyld. Et eksempel på dette kan være når barnet som er såret av en annen, blir bedt om å legge dette bak seg uten at det blir tatt et oppgiør hvor ansvaret blir plassert. Det bidrar til en forestilling om at det vonde ikke er så ille, og at det viktigste er å tilgi og glemme det som har skjedd.

\section{Et relasjonelt fokus:}

Tilgivelse som et mellommenneskelig anliggende Tilgivelse har så å si alltid noe med en annen å gjøre. ${ }^{13}$ Det betyr at en avklaring av relasjonens innhold er bestemmende for om og hvordan tilgivelse og forsoning kan skje. Litteraturen som primært tar utgangspunkt i dette fokuset, tydeliggjør hvilke konsekvenser forsoning og tilgivelse kan ha for begge parter på godt og vondt. Fellesnevneren i perspektivet er at den tydeliggiør tilgivelsen som et resultat av en forsoningsprosess.

Tilgivelsen oppfattes som en tosidig prosess, og hvor tilgivelse forstås mer som utbytte enn som premiss (Armour og Umbreit, 2005). Tilgivelse angår ofte også flere enn de som direkte er involvert. De som er til stede der devaluerende

12 Roar Iversen (2013) behandler og drøfter i sin doktoravhandling Enrights forståelse av tilgivelse. Både Worthington og Enright er sentrale aktører i USA innen forskning og arbeid knyttet til spørsmål om tilgivelse og forsoning.

13 Å tilgi seg selv (kalt livsforsoning tidligere i artikkelen) kan være et eksempel på tilgivelse som ikke nødvendigvis har direkte med andre å gjøre. Like fullt er et oppgjør med en destruktiv skyld svært sjelden uavhengig av andre. 
hendelser skjer mellom mennesker, som andre familiemedlemmer, barnehagegruppa, skoleklassen eller trosopplæringsarenaen, er nøkkelpersoner i et mulig forsoningsarbeid. Farhad Dalal (2016, s. 230) skriver at tilgivelse ikke er et arbeid for «enestående enkeltmennesker» ${ }^{14}$, men likeså mye for de som tilhører sammenhengen hvor behovet for tilgivelse aktualiseres. «We are these others» konkluderer han med.

Dette «vi» innebærer at den som kan gi tilgivelse, ifølge Bengt Thurfjell (2003, s. 53), er et speil som tydeliggjør den andres menneskelighet. Denne samhørigheten forankrer han i en forståelse av tilgivelse som «upprättelse från skam». For den sårede betyr det en rettighet til å slippe å tilgi. For den som har såret, betyr det å bære sin menneskelighet ved å erkjenne skyld og ansvar. Å beskrive samhørighet når utgangspunktet er ødelagte relasjoner, er motsetningsfylt. Perspektivet bidrar imidlertid til at fokus flyttes ved at «tilgivelsen retter seg mot personen snarere enn gjerningen»(Leer-Salvesen, 2009, 120). Forsoning vil da redefinere relasjonen mellom partene (Bloomfield, 2003, s. 12) ${ }^{15}$ Mennesket er «noe mer enn de handlinger som jeg har påført meg skyld ved» (Henriksen 2008, 208). Det er et generelt anliggende, men kan også bidra til bedre å forstå tilgivelsens vesen.

I praksis innebærer dette både evne og vilje til det som psykologien kaller «mentalisering». Begrepet kan være til hjelp for å forstå muligheter og begrensninger i situasjoner hvor forsoning og tilgivelse blir aktualisert. Begrepet er definert på følgende måte:

When we mentalize we are engaged in a form of (mostly preconscious) imaginative mental activity that enables us to perceive and interpret human behaviour in terms of intentional mental states e.g. needs, desires, feelings, beliefs, goal, purposes and reasons (Fonagy \& Allison, 2012, s. 11).

Mentalisering er det enkelte menneskes evne og vilje til å sette seg inn i den andres opplevelse og forståelse av det som har skjedd. Dette er åpenbart avhengig av modenhetsnivå. Det er også ofte avhengig av en viss distanse i tid til den konkrete hendelsen. Kapasitet til å mentalisere er i tillegg ulikt fra person til person. Evnen til å sette seg inn i et annet menneskes perspektiv når en selv er involvert i situasjonen, er avhengig både av bakgrunnen for det som skjedde og personlighetsfaktorer.

John Patton (2003, s. 176) beskriver tilgivelse som en oppdagelse av noe som allerede har skjedd. Oppdagelsen av tilgivelsens realitet mottas som en gave både for den som er såret og den som skapte såret. Erkjennelsen er basert på at den som såret, er et medmenneske med flere likhetstrekk med en selv enn det motsatte. «I am able to forgive when I discover that I am in no position to forgive» er Pattons paradoksale konklusjon. Prosessens mål er et oppgjør med det onde hvor den skyldige eier sin skyld og den utsatte ikke lenger bærer ansvar, skyld og skam for

14 Dette er på engelsk uttrykt som «a solitary individual».

15 Blomfield sier at forsoning «redesigns the relationship between us» 
det som har skjedd (Kleiven 2010). Tilgivelse som et resultat av et slikt oppgjør er en overraskende bonus. Dette perspektivet kan også ha som konsekvens det som de Gruchy $(2002,177)$ kaller «turning of the tables» ved at maktforholdet mellom partene endres.

Mulighet for misbruk er til stede også innenfor dette perspektivet. Peter Horsfield (2002) beskriver hvordan tilgivelse kan brukes som et redskap til å unngå det ubehagelige som skandaler, konflikt og disharmoni. Dette skjer når den som er såret, blir presset til å «tilgi og glemme», eller anvender tilgivelse som et middel til å forhindre represalier og forhindre trusler fra den sterke part.

\section{ULIKE TILNÆRMINGER SETT I SAMMENHENG}

Denne gjennomgangen har sett på ulike tilnærminger til tilgivelsens innhold som finnes i faglitteraturen, systematisert og drøftet som tre ulike perspektiver. Det er samtidig et poeng å sammenholde tilnærmingene som vesentlige bidrag til å forstå fenomenet og begrepet tilgivelse. Målet er å finne svar på hvordan oppgjør, forsoning og tilgivelse kan fungere som en frigiørende mulighet for både den krenkede, krenkeren og de som er en del av sammenhengen hvor krenkelser har skjedd.

Neste hoveddel søker etter å anvende presentert teori og analyse til å diskutere hvordan tilgivelse kan relateres til møter med barn og unge. Følgende er et forsøk på å sammenholde elementer fra ulike tilnærminger til tilgivelse som et grunnlag for drøftingen som følger:

- Tilgivelse er ikke et mål i seg selv, men et mulig resultat av et oppgjør basert på ansvarsavklaring og ansvarsplassering ut fra rolle og posisjon i hendelsen.

- Tilgivelse er først og fremst en oppdagelse hos den som er såret, av å ha fått en endret posisjon til den som har såret.

- Et bidrag til at dette kan skje, er å tilrettelegge en prosess som aktualiserer forsoningsarbeid hos den som er såret, den som er anklaget, og mellom de som hendelsen for øvrig angår.

\section{Tilgivelse og FORSONINGSARBEID I MØTE MED BARN OG UNGE}

Problemstillingens andre del spør etter hvordan tilgivelse kan formidles og praktiseres i møte med barn og unge. Drøftingen har som mål å gi noen svar på dette sett $\mathrm{i}$ lys av den analysen som er gjort. Jeg har ikke valgt en avgrenset aldersgruppe blant barn og unge, men tilnærmingen i språk og form vil naturlig nok ha ulikt innhold og aktualitet ut fra modenhetsgrad og kontekst. De mest nærliggende arenaene hvor tilgivelse kan formidles og praktiseres, er i denne artikkelen knyttet til hjem, barnehage, skole og $i$ trosopplæringssammenheng. I disse arenaene er det muligheter for å ha en bevisst strategi for hvordan voksne møter barn og hvordan 
barn kan møte hverandre når konflikt oppstår og en av eller begge parter opplever seg såret. Fokus er ikke på undervisning om forsoning og tilgivelse generelt, men å drøfte hvordan en kan forholde seg til situasjoner hvor en eller begge parter opplever seg utsatt for urett. Det gir mulighet for å modellere forsoningsarbeid og plassere tilgivelse inn i en frigjørende sammenheng. Dette omfatter både de to partene som dette primært gjelder for, men også for de som er en del av et «vi» (Dalal, 2016) ved å være til stede i det som skjer.

Barnet og ungdommen kommer med sin historie om opplevelse av urett og av å ha blitt tråkket på. Tiåringen står der med masse sinne og tårer fordi noen tok ballen fra ham. En venninne i skolegården gikk sin vei. En kamerat ble sint og slo den andre. Fortellingen kan oppleves bagatellmessig. Hendelser står imidlertid aldri isolert. Hvor dyptpløyende opplevelsen er for den som forteller, kan ikke bare måles på de faktiske hendelsene. Det er mennesker med en livshistorie som møtes, og hvor ord og handling kan ramme sår som allerede er dype.

Det er ikke mulig å planlegge når barnet og ungdommen kommer med sin historie. Derfor er det nødvendig med en beredskap for å kunne gå situasjonen $\mathrm{i}$ møte når det skjer. Det er samtidig nødvendig å ha en strategi for hvordan en slik situasjon skal følges opp på en kompetent og konstruktiv måte i møte med den som opplever urett og den som anklages.

\section{En forståelse av tilgivelse}

Jeg har tidligere oppsummert hvordan tilgivelse kan forstås basert på refleksjonen over sentrale elementer i analysematerialet. Denne oppsummeringen legger jeg til grunn i behandlingen av temaene i denne delen av artikkelen. Diskusjonen som følger, er basert på at tilgivelse ikke er et mål $i$ seg selv. Målet er snarere et oppgjør hvor ansvar avklares og plasseres. Tilgivelse er da snarere en mulig bonus av en prosess hvor tilgivelse oppleves og oppdages som et resultat. Tilgivelsen oppfattes da i beste fall som en frigjørende og overraskende gave, ikke bare for den som tilgis, men også for den som tilgir. Kierkegaard beskriver dette som en kjærlighetspraksis hvor de som er involvert «believes the visible away» slik G. P. Marcar (2019, s. 719) oversetter Kierkegaard (2011, s 102).

Faglitteratur som betoner et relasjonelt fokus på tilgivelse, hevder at det er mulig å legge til rette for en prosess hvor forsoning muliggiøres og hvor tilgivelse kan bli et (utilsiktet) resultat. Mentalisering er, som tidligere beskrevet, det enkelte menneskes evne og vilje til å sette seg inn i den andres opplevelse og forståelse av det som har skjedd. Det er mulig å utvikle kapasitet til mentalisering når tilgivelse blir aktualisert. Faglige tilnærminger knyttet til et intrapsykisk fokus på tilgivelse kan bidra til økt mentaliseringskompetanse hos den som har opplevd urett (Worthington, 2006). Tilsvarende tilnærminger kan brukes overfor den som er anklaget. En erkjennelse av minner som et begrenset og perspektivfor- 
ankret sannhetsvitne (Levi,1989; Volf 2006) er et viktig bidrag til å motivere for $ø k t$ mentaliseringsvilje. Gunnestad, Mørreaunet og Onyango (2015) beskriver en prosessuell tilnærming til tilgivelse og forsoning. Denne tydeliggiør hva resultatet av en mentaliseringsprosess kan inneholde når denne prosessen går parallelt hos både den som er krenket og den som krenker. Den krenkedes prosess er erkjennelsen av å ha blitt såret og tråkket på og vilje til å snakke med noen om dette. Den anklagedes prosess innebærer å forstå at den andre er blitt såret, kjenne på anger og et behov for å ta ansvar. Å gi og motta tilgivelse kan bidra til oppreisning for den krenkede, men også en gjensidig respekt og frigjørende erfaring for begge parter.

\section{Å såre og bli såret - maktmidler i samspill}

Den Sørafrikanske fredsprosessen etablerte betegnelsen «Truth and Reconciliation Commission» (TRC) som et grunnlag for oppgjøret med apartheid (Fullard og Rousseau, 2009; Solomon, 2020). Fokus på «truth-telling» ble anvendt som et avgjørende virkemiddel. Både betegnelsen og innholdet $\mathrm{i}$ denne prosessen er senere blitt brukt som modell i andre store konflikter på nasjonalt nivå (Bar-Tal og Bennink, 2004, s. 29) og også anvendt i en prosess knyttet til samisk kultur (Johnsen \& Skum, 2013). ${ }^{16}$ Det kan synes å være en lang vei fra nasjonale og regionale fredsprosesser til en tolvårings behov for å bli tatt på alvor etter å ha blitt såret. Det er likevel noen grunnleggende kjennetegn ved denne typen prosesser som kan ha overføringsverdi. Både tolvåringen som var utsatt for mobbing $\mathrm{i}$ skolegården og den som var rammet av voldsbruk fra apartheidregimet, har behov for en motstemme utenfra. En motstemme innebærer i denne sammenhengen at en utenforstående formidler at opplevelsen av ansvar, skyld og skam er en påført virkelighetsforståelse som en del av krenkelsen vedkommende har blitt utsatt for. Et viktig poeng som nettopp TRC illustrerer, er at den som er anklaget for urett, kan fortelle sin historie, men også lytte til den som opplever å ha blitt utsatt for urett av ham eller henne. Dette er et premiss for at tilgivelse og forsoning kan bli aktualisert som et mulig resultat av et oppgjer basert på ansvarsavklaring og ansvarsplassering ut fra rolle og posisjon $i$ hendelsen.

TRC sitt utgangspunkt er at den med størst makt har brukt sin posisjon til å krenke den andre. Krenkelsene er faktiske hendelser som har skjedd. Ansvaret for om makten brukes til å ivareta eller krenke den andre ligger alltid hos den som forvalter en overmakt. Den voksne eller et vesentlig eldre barn vil alltid være i en overmaktsposisjon i møte med et barn. En maktanalytisk tilnærming innebærer at ansvar kan plasseres basert på maktforholdet mellom partene (Kleiven, 2010, s. 95-99). Det er viktig å avsløre at tilgivelse kan misbrukes ved å slippe ansvar eller redusere ubehag (Horsfield, 2002). Når barnet eller ungdommen oppdager at å si «unnskyld» betyr å ha gjort det som er nødvendig for å slippe billigst mulig

16 Stortinget nedsatte en sannhets- og forsoningskommisjon for å for å granske fornorskingspolitikk og urett overfor samer, kvener og norskfinner; se https://uit.no/kommisjonen for mere informasjon. 
unna anklagen, kan det snarere være en ny krenkelse mot den som er såret enn et oppgjør hvor ansvar plasseres. En voksen eller ungdom kan misbruke sin maktposisjon i møte med en tolvåring som opplever seg tråkket på, ved å bagatellisere hendelsen eller ved å ikke ta ham eller henne på alvor. En erkjennelse av ansvar kan imidlertid også misbrukes av den som er såret når det brukes som et våpen for å oppnå fordeler. Maktasymmetri i relasjonen betyr like fullt at faren er langt større for at den sterke part kan ramme den svake part enn det motsatte. Ikke minst kan den sterke part misbruke sin definisjonsmakt over virkelighetsforståelsen både før og etter at ansvaret i situasjonen er klarlagt.

TRC kan ha en overføringsverdi i den prosessuelle tilnærmingen til et oppgjør. TCR hadde som utgangspunkt at den svake part fortalte sin historie om krenkelser («truth-telling»). Historiens troverdighet er knyttet til sannsynligheten av at hendelsene faktisk har funnet sted. Noen ganger kan det være utfordrende når ord står mot ord, men det er sannsynlig at en i de fleste tilfeller kan få en tilnærmet lik beskrivelse av de faktiske hendelsene (Bjerva, 2009, s. 62). ${ }^{17}$ Opplevelsen av å ha blitt såret er imidlertid ikke gjenstand for en vurdering av troverdighet. Den skal respekteres som fortellerens eiendom. Samtidig skal fortellingen vurderes på om det er andre forhold enn et behov for å få oppreisning som kan spille inn. Eksempler på dette kan være behov for hevn eller å anvende hendelsen til å opparbeide seg en posisjon overfor autoritetspersoner.

\section{«Det var ikke jeg som begynte»}

Forutsetninger for oppgjør er å klargjøre hva som har skjedd og opplevelsen av det som har skjedd. Det betyr at begge parter skal bli hørt for å muliggjøre en forsoningsprosess. Både den sårede og den som er anklaget for å ha såret den andre, beskriver hendelsen ut fra sitt perspektiv. Beskrivelsen er subjektiv og påvirker forståelsen av hva som har skjedd. «Hvem som begynte» blir ikke sjeldent brukt som argument for at en selv er uskyldig. Dette er nok et argument for å anvende en maktanalytisk tilnærming for å avklare hvem som har et hovedansvar. En tilnærming som kan aktualisere tilgivelse og forsoning, forutsetter imidlertid ikke enighet om alt som har skjedd og «hvem som begynte». Det handler i større grad om at den som er såret, blir møtt med en grunnleggende respekt fra den andre part for å ha blitt såret. Når noen eksempelvis latterliggjør den andre, er en vei mot forsoning å få denne personen til å sette seg inn i hvordan det kunne oppleves om en selv ble utsatt for det samme. Dette åpner opp for å kunne oppdage at forsoning og tilgivelse handler mer om hverandres menneskeverd enn om handlingen i seg selv (Leer-Salvesen 2009, 120). En oppdagelse av den andre som et medmenneske gir et grunnlag for å «redesign the relationship» (Bloomfield, 2003, s. 12). Det

17 Bjerva gjorde en undersøkelse av ca 300 saker i kirkelig sammenheng hvor en hadde håndtert anklager om seksuelle krenkelser gjort av tillitspersoner. I $90 \%$ av tilfellene erkjente den anklagede hele eller deler av de faktiske forholdene. 
samsvarer også med forståelse av tilgivelse som en oppdagelse hos den som er såret, av å ha fätt en endret posisjon til den som har såret.

\section{«Jeg glemmer ikke hva han gjorde mot meg»}

En sterk tradisjon $\mathrm{i}$ kristen trosformidling er uttrykket å «tilgi og glemme» (Kleiven, 2011, s. 42). Tilgivelse kan oppfattes som ensbetydende med å glemme det som har skjedd. Om barn og ungdom som opplever å ha blitt dypt såret, får beskjed om å tilgi og glemme, øker det risikoen for at hendelsen preger opplevelsen av egenverdi og forholdet mellom de som var involvert på en ødeleggende og degraderende måte.

Tilgivelsens aktualitet starter som nevnt med at den som er såret, erkjenner å ha blitt såret. Det kan være en utfordring på flere plan. Det ene er forestillingen om at å fortelle at en er blitt såret, er å vise svakhet. Selve hendelsen kan også påføre den sårede en urettmessig forståelse av å være ansvarlig og skyldig i det som skjedde. Begge deler innebærer økt skam. Thurfjell (2003, s. 54) beskriver tilgivelse som «upprättelse från skam». Det forutsetter det motsatte av å glemme. Det betyr bistand til å rydde, avklare og erkjenne. Når ungdommen forteller om foreldre som anklager ham eller henne for ikke å være god nok, er det avgjørende å ha tilstrekkelig tid til å lytte, spørre og bidra til at den vonde opplevelsen blir godkjent som sårende. Det gir muligheter for at anklagenes preg på selvbilde får en motstemme. En slik bearbeidingsprosess kan betegnes som livsforsoning (Leenderts, 2018, s. 179; Kleiven, 2015, s. 189). Dette er en prosess som ikke er avhengig av hvordan foreldrene forholder seg til det urettmessige de har påført barnet sitt. Teori knyttet til minneforståelse tydeliggjør samtidig hvordan egne minner alltid kan endres og dermed utvide fortellingens innhold (Volf, 2006, s. 50). Minner er da ikke bare kunnskap om hva som har skjedd, men et handlingsrom for hvordan minner kan forstås. Det åpner opp for muligheter til å se hva som skjedde sett fra andre aktørers posisjon (mentalisering), men også til å godkjenne egen begrensning (svakhet) og manglende muligheter til å hindre det vonde som en er blitt påført. Opplevelsen hos ungdommen av å ha blitt tråkket på, skal godkjennes, og fortellingen til den som er anklaget, skal møtes med respekt. Samtidig er det for begge parter viktig å legge til rette for muligheter til å forstå hendelsen fra flere synsvinkler og posisjoner.

Tilgivelse innebærer å tilrettelegge en prosess både hos den som er såret, og mellom de involverte $i$ hendelsen, som aktualiserer forsoningsarbeid hos den som er såret, og mellom de som hendelsen angår. Et intrapsykisk fokus på tilgivelse kan bidra til at både den sårede og den som har såret, bearbeider hendelsen gjennom mentalisering og minneforståelse. Et relasjonelt fokus på tilgivelse kan muliggjøre en forsoningsprosess mellom de som hendelsen angår. En forsoningsprosess er det motsatte av å tilgi og glemme. Det er å huske det som skjedde på en ny måte, og som gjør både livsforsoning og forsoningsarbeid mellom de involverte mulig. 


\section{Skal vi be om tilgivelse?}

Å be om tilgivelse når en har gjort noe urett mot et annet menneske, er for mange både nødvendig og det som er rett. Ikke minst i oppdragelsen brukes dette som et middel for å styrke forståelsen av ansvar hos barn og unge. En slik strategi kan muligens bidra til økt ansvarsforståelse der hvor hendelsene er mulig å gjøre opp der og da. Avklaringen gjøres raskt, og hendelsen har ikke etterlatt seg dype sår. Men et grunnleggende spørsmål er likevel om det er rett å be tilgivelse etter å ha såret et medmenneske? Det er ofte en nærliggende forståelse at det å be om tilgivelse for å ha begått urett, betyr å ta ansvar. Dette er dessverre en etablert forståelse $\mathrm{i}$ kristen trosformidling og også pregende for store deler av vår kultur. Dette forsterkes ytterligere når det knyttes sammen med at det å svare ja på spørsmålet om en vil tilgi den andre, oppfattes som en kristenplikt (Kleiven, 2011 og 2016). I praksis misbrukes tilgivelsen da til å frita den ansvarlige fra å bære konsekvensene for uretten som er begått. Det er derfor god grunn til å stille spørsmål ved om praksisen med å be om tilgivelse er formålstjenlig. En alternativ praksis kan snarere være å tydeliggjøre overfor den som er rammet at en erkjenner ansvaret for å ha begått urett, og viser dette både i ord (for eksempel ved å si «unnskyld»), i holdning og handling. Dette mener jeg i større grad legger til rette for at den sårede oppdager at en både kan og vil formidle at en tilgir den andre fordi en allerede har gjort det.

Et perspektiv ved det teologiske fokus på tilgivelse er at den forstås som et kjennetegn ved det kristne fellesskap. Det innebærer at tilgivelse ikke først og fremst er ord eller konkrete handlinger, men «an embodied way of life in an ever-deepening friendship with the Triune God and with others» (Jones, 1995, s. xii). Selv om dette er knyttet mer eksplisitt til det kristne fellesskapet, kan denne forståelsen også anvendes mer generelt som kjennetegn ved frigjørende fellesskap og sunne relasjoner. Tilgivelsens mulighet beskrives da som en konsekvens av relasjoner og fellesskap som tar oppgjør med urett og plasserer ansvar. Det innebærer en kulturbygging som kontinuerlig modellerer åpenhet om både det gode og utfordrende i relasjonelt samspill, og som praktiserer forsoningsarbeid i det daglige. Tilgivelse forstått som «an embodied way of life» innebærer at tilgivelse er en oppdagelse hos den som er såret, av å ha fätt en endret posisjon til den som har såret. De vonde hendelsene knyttes i større grad til relasjoner som avklares og endres, noe antagelig barn kan ha bedre forutsetning til enn voksne. Det håpefulle $i$ en slik forsoningskultur hvor tilgivelse kan gis og tas imot som en overraskende bonus, er at fortiden ikke lenger definerer nåtid og framtid (Mordechai,2015, s. 502; Staub, 2005, s. 444). Fortiden vil da først og fremst endre karakter slik at den bidrar til at barnet (og den voksne) i større grad kan leve her og nå og med blikket rettet framover. Trygge voksne som i møte med barn og unge kan modellere en prosess hvor relasjoner avklares og endres, vil bidra til at tilgivelse gis og forsoning skapes, i stedet for at tilgivelse etterspørres eller kreves. 


\section{OPPSUMMERENDE KONKLUSJON}

Artikkelens problemstilling etterspør hvordan tilgivelse beskrives innen faglitteratur. Første del presenterer og diskuterer dette ved å analysere faglitteraturens beskrivelser og definisjoner. Analysen er samtidig en drøfting av ulike tilnærminger til begrepet som litteraturen presenterer både generelt og med referanse til målgruppa barn og unge. En sammenstilling av noen elementer fra beskrivelser av tilgivelsens innhold anvendes som en fortolkende nøkkel i artikkelens andre del. Her diskuteres mer eksplisitt formidling og praktisering av forsoningsarbeid i møte med barn og unge. Artikkelen anvender også minneforståelse som et teoretisk perspektiv i forståelse og praktisering av tilgivelse og forsoningsarbeid. Fortolkningsnøkkelen som anvendes, er et bidrag til å operasjonalisere tilgivelsens innhold i møte med barn og unge. Dette er, ut fra de rammene artikkelen gir, gjort på et nokså overordnet nivå. Tre av hovedpunktene som er vektlagt i formidling og praktisering av tilgivelse, er

- Tilgivelse er ikke et mål i seg selv, men et mulig resultat av et oppgjør.

- Tilgivelse innebærer en oppdagelse av at den som er såret, har fătt en endret posisjon til den som har såret. Dette underbygger at tilgivelse innebærer et endret forhold til en annen person mer enn en punktuell respons på en sårende handling.

- Tilgivelse og forsoning betyr å modellere en livsforståelse hvor utvikling av kompetanse til empatisk forståelse (mentalisering) blir verdsatt og praktisert.

Forhåpentligvis kan disse brukes til å forankre en praksis som i framtidig arbeid kan formidles med en større grad av konkretisering og ikke bare på et overordnet nivå.

\section{LitTERATUR}

Fonagy, P. \& Allison, E (2012). «What is Mentalization? The Concept and its

Foundation in Developmental Research and Social-Cognitive Neuroscience.»

I Nick Medgley \& Ioanna Vrouva; Minding the Child Mentalization-Based

Interventions with Children, Young People and their and their Families. New York:

Routledge

Armour, Marilyn Peterson og Mark S. Umbreit (2005). «The Paradox of

Forgiveness in Restorative Justice.» I Everett L. Worthington, Jr (red),

Handbook in Forgiveness. New York: Routledge, 161-182

Aubsburger, D. W. (1996). Helping People Forgive. Louisville: Westminster John

Knox Press

Bar-Tal, D. \& Gemma H. B. (2004). «The Nature of Reconciliation as an

Outcome and a Process.» I Bar-Simon-Tov, Y. (red.): From Conflict Resolution

to Reconciliation. Oxford, OUP, 11-38

Bash, A. (2007). Forgiveness and Christian Ethics. Cambridge: Cambridge

University Press 
Bloomfield, D. (2003). «Reconciliation. An Introduction.» I Bloomfield, Barnes \& Huyse (eds.), Reconciliation after Violent Conflict. A Handbook. Stockholm, IDEA, 10-18.

Bjerva, E. K. (2009). Når ord står mot ord. Kirkens håndtering av seksuelle krenkelsesanklager mot sine ledere når ord står mot ord - i lys av et diakonifaglig perspektiv. Oslo: Det Teologiske Menighetsfakultet (Masteravhandling)

Bråkenhielm, C.-R. (1987). Förlåtelse. En filosofisk och teologisk analys. Stockholm: Proprius Förlag

Dalal, Farhad (2016). «Forgiving the Unforgivable. Mortals, Saints and Sinners.» Sage Journals Vol. 49(3): 216-232; DOI: 10.1177/0533316416656933

De Gruchy, J. W. (2002). Reconciliation - Restoring Justice. London: SCM

De Lange, F. (2004). «Room for Forgiveness? Theological Perspective.» I Didier Pollefeyt (red.), Incredible Forgiveness. Christian Ethics between Fanaticism and Reconciliation Leuven: Peeters, 161-182

Dwyer, Susan (2003). «Reconciliation for Realists.» Carol AL Prager \& Trudy Govier (red.): Dilemmas of Reconciliation. Cases and Concepts. Waterloo, Ontario, Wilfrid Laurier University Press, 91-110.

Enright, R. D. (2001). Forgiving as a Choice. A Step-by-Step Process for Resolving Anger and Restoring Hope. Washington DC: APA LifeTools Fullard og Rousseau

Gamlund, E. (2009). A Change of Heart. Essays in the Moral Philosophy of Forgiveness. Oslo: Universitet i Oslo (PhD-avhandling)

Gunnestad, A., Mørreaunet, S. \& Onyango, S. (2015). «An international perspective on value learning in the kindergarten - exemplified by the value of forgiveness.» I: Early Child Development and Care. Routledge.

Hammerlin, Y. \& Leer-Salvesen, P. (2014), Voldens ansikter. En dialog om ondskap, ansvar og håp. Oslo: Cappelen Damm Akademisk

Henriksen, J.-O. (2008). «Forsoning, oppgjør og tilgivelse.» I Bekken (red), Fengselsliv og menneskeverd. Oslo: Verbum, 198-217

Holloway, R. (2002). ON Forgiveness. How can we forgive the unforgivable?

Edinburgh: Canongate Books Ltd

Horsfield, P. (2002) «Forgiving Abuse. An Ethical Critique.» In Journal of Religion \& Abuse Vol 4 (4), 52-70

Iversen, R. (2013). Barmhjertighet og frigjoring. Sjelesorg som hermeneutisk praksis. Refleksjon i grenselandet mellom teologi og filosofi. (Doktoravhandling for graden $\mathrm{PhD}$ ). Trondheim/Oslo: St. Olavs Hospital og Det teologiske menighetsfakultet

Jankélévitch, V. (2005). Forgiveness. Chicago: The University of Chicago Press Johnsen, T \& Skum, L.M. (red) (2013). Erkjenne fortid-forme framtid. Innspill til kirkelig forsoningsarbeid i Sápmi. Stamsund: Orkana 
Jones, L. G. (1995). Embodying Forgiveness. A Theological Analysis. Grand Rapids: William B. Eerdmans Publishing Company

Keene, Fredrich W. (1995). «Structures of Forgiveness in the New Testament.» I C. J. Adams \& M. Fortune (red.) Violence against Women and Children. A Christian Theological Sourcebook. New York: Continuum

Kierkegaard, S. ([1847] 2011) Kjerlighedens Gjerninger. Nogle christelige Overveielser i Talers Form.

København: København Universitet, Søren Kierkegaard Forskningscenteret, elektronisk version $1.6 \mathrm{http}: / / \mathrm{sks} . \mathrm{dk} / \mathrm{KG} / \mathrm{txt} . \mathrm{xml}$

Kleiven, T. (2010). Intimitetsgrenser og tillitsmakt. Oslo: Diakonova

Kleiven, T. (2016). «Makt til å tilgi. Guds tilgivelse og mellommenneskelig tilgivelse sett i et maktanalytisk perspektiv.» Tidsskrift for Sjelesorg 2, 151-168

Kleiven, T. (2011). »'Slik som vi tilgir våre skyldnere'. Å tilgi sin neste evangelium eller kristenplikt?» I Halvårsskrift for praktisk teologi nr. 1, 40-50

Kleiven, T. (2015). «Å leve med sin livshistorie. Om premisser i møte med unges smertefulle erfaringer.»I L.G. Engedal, T. Fagermoen, A. Sandsmark (red.) Trosopplaring for alle? Laring, tro og sårbare ungdom. Oslo: IKO-Forlaget (Prismet bok)

Konstan, D. (2010). Before Forgiveness. The Origins of a Moral Idea. Cambridge: Cambridge University Press

Leenderts, T. Aa. (2018). I mote med lidelsen - finnes det en kjorlig Gud? Son: Kom forlag

Leer-Salvesen, P. (2009). Forsoning etter krenkelser. Bergen: Fagbokforlaget

Levi, P. (1989). The Drowned and the Saved. New York: Vintage International

Luther, M. (1952). Store katekisme. Gjøvik: Det Evangelisk-Lutherske Kirkesamfunn

Marcar, G.P. (2019). «Søren Kierkegaard and the impossibility of (un) forgiveness. Another Look at Love, Mercy, and Reconciliation in Kierkegaard's Theological Ethics.» Journal of Religious Ethics Vol 47-4 https://doi.org/10.1111/jore.12288

Gordon M. (2015) «Between Remembering and Forgetting.»Dordrecth: Stud Philos Educ34:489-503 DOI 10.1007/s11217-014-9451-2

Murphy, J. G. (2003). Getting Even. Oxford: Oxford University Press

Patton, J. (2003). Is Human Forgiveness Possible? A Pastoral Care Perspective. Lima: Academic Renewal Press

Riceour, P. (2004). Memory, History, Forgetting. London/Chicago: The University of Chicago Press

Rothermel, D. (2011). «Introduction.» I R. Gildert \& D. Rothermel (red.), Remembrance and Reconciliation. Amsterdam-New York: Rodopi B.V., 3-6

Solomon, D. J. (2020). «Re-examining a theology of reconciliation. What we 
learn from the Kairos Document and its pedagogical implications.» HTS Teologiese Studies/Theological Studies

Staub, E. (2005). «Constructive rather than Harmful Forgiveness. Reconciliation and ways to Promote Them After Genocide and Mass Killing.» E.L Worthington Jr (red.), Handbook of Forgiveness. New York: Routledge, $443-460$

Thurfjell, B. (2003). «Guds förlåtelse och människans ansvar.» Tidsskrift for Sjelesorg $n r$ 1, 43-53

Volf, M. (2006). The End of Memory. Remembering Rightly in a Violent World. Grand Rapids: Wm. B. Eerdmans Publishing Co.

Worthington, E. L., Jr (2006). Forgiving and Reconciling. Theory and Application. New York: Routledge 